\title{
Increasing Brand Awareness of Keka Catering Through Social Media "Instagram"
}

\author{
Kezia Callista \\ English Department, Faculty of Languages and Literature, \\ Petra Christian University, Siwalankerto 121-131, Surabaya 60236, INDONESIA \\ E-mail: m11416026@john.petra.ac.id
}

\begin{abstract}
This creative thesis to solve the problem that KeKa Catering has. KeKa Catering is different with the general catering which serve it daily and has same menu. However, KeKa Catering has different menu which are Banjarmasin's foods and snacks. Their problem is there is still many people who do not recognize their brand or product. Even though KeKa Catering already has their promotional tool, which is Instagram, but they do not use it properly. That is why developing their Instagram account is the best way. It is because will cost less than marketing booklet and the other tools. There are 12 contents on their Instagram account. The customer of KeKa Catering is around 25 until 35 years old. That is why I use slang or internet word for the choice of language. With Instagram the target customers are broader, and many people will recognize easily.
\end{abstract}

Keywords: brand awareness, catering, social media, Instagram

\section{INTRODUCTION}

During my internship program, I found out that the owner cannot promote her product properly. It is because as I had seen during my internship program, there is only 1 new customer in the first month. However, in the second month of my internship program, there are three new customers which are quite good. In the last month of my internship program, the number of new customers has decreased which are only two new customers. KeKa Catering already has its promotion tool, which is Instagram, but I found out that it is not effective enough to promote their product. It is because as I have seen on their Instagram, I found out that their following profile on Instagram is not working well. Also, they are not using their Instagram properly. A reason their Instagram business account is not working like it is supposed to be is that they are not uploading their content properly. It means they do not have an exact time or schedule to upload their content. Furthermore, it is because they are still developing their product. They rarely upload their product and put a proper caption to describe it.

KeKa Catering needs to increase its promotion. It is because the one who knows their product is only their close friend or who already knows them. Even though they already have an Instagram account, it is not run well. It is not going well because the owner cannot use that tool properly. Also, they do not really understand how to manage Instagram to get customer's attention. Furthermore, their Instagram account is not constantly uploaded about their product. Besides that, sometimes the photos that they take are not eye-catching enough. That is why KeKa Catering needs to develop its Instagram account. It is because there are so many Instagram users and it is useful enough to promote small businesses. With Instagram as their online marketing platform, they can promote their product and make their new customer curious about their product, and they are willing to buy KeKa Catering's product. 
Callista: Increasing Brand Awareness of Keka Catering

Through Social Media "Instagram"

There is some support theory that I used for this creative thesis. First is brand awareness, according to Sasmita and Suki (2014) brand awareness is how customers feel related to the product of the brand. A business needs brand awareness to build communication with the customer. It is impactful for the customer and the businessman because it is basically where the customer makes decisions about the product that businesses have. KeKa Catering has its own way to build a communication with their customer which is through social media, especially Instagram. According to Merriam Webster (2020), "social media is forms of electronic communication (such as websites for social networking and microblogging) through which users create online communities to share information, ideas, personal messages, and other content (such as videos)". That is why engagement is the key to social media. Social media entails building a platform for your target markets to communicate with you and maintaining those relationships (Howard, Mangold, Johnston, 2014).

Instagram is one of the most used social network services, photos, and or video sharing. Almost everyone is using Instagram. Since June 2018 there are almost 500 million active users of online platforms, and approximately 120 people are using Instagram (Clement, 2020). There is a "hashtag" system on Instagram to help to share photos and videos easier. Instagram is not just a platform for sharing photos and videos but also for marketing and brand promotion. An Instagram profile is the picture of the brand that the business has. Content that a businessman has is the key to the future as well as a success (Bansal, 2018). Instagram is the platform to communicate ideas and ideals with different manners to have interaction between brand and consumers in nowadays era (Robertson, 2018). Also, maintaining the communication between the customer and the owner is one of the main keys to developing a business because the business could gain followers, by showing to the customer that a business cares about their critics and feedback. The Instagram business account's followers could be the one who influences the success because the customer builds their trust of the product from this, that is why the owner should never underestimate their follower (Massage and Spa, 2020).

\section{METHOD}

The data were collected by giving both kinds of customers who known KeKa Catering and who do not know KeKa Catering through online surveys. Due to this pandemic of COVID-19 KeKa Catering chose to give the customer online surveys instead of offline or meet them one by one. The online survey that I made was using a google form because it is the easiest way for the customer and to resume the data collection. I made three different questionnaires which are the first questionnaire for both those who do not know about KeKa Catering and whoever buys KeKa Catering product, the second questionnaire is for the repeater order customers, and the last questionnaire for the one who does not know any information about KeKa Catering.

For the first questionnaire, there are four sections, this questionnaire for both kinds of respondents. Meanwhile, the second questionnaire has two sections, and the last one which is for the one who does not know and or never buys KeKa Catering products has there are four sections.

\section{FINDINGS AND DISCUSSION}

There are four sections for the first questionnaire. This questionnaire was filled up by the general customers which mean it was spread to whoever buys or knows KeKa Catering and for the one who never or knows KeKa Catering's products. The second questionnaire was for the repeater 
order customer. There were two sections for this questionnaire. The first section was the respondent's background, then about the KeKa Catering itself. The last questionnaire is for the one who never bought KeKa Catering's product and or did not know anything about KeKa Catering. There were four sections for this questionnaire. Here some examples of the questionnaire that I spread.

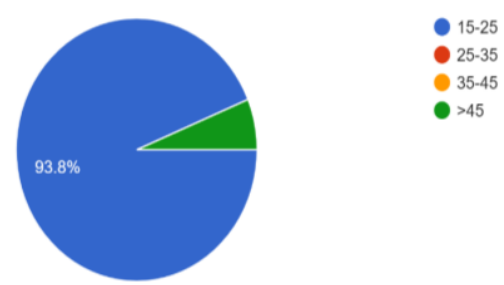

There is respondent's age in every question for respondent's background. It is because the first important information about the respondent's background is their age. It is based on the choice of language that is going to be used for Instagram's account. According to the theory of language use for online marketing, younger people tend to use internet words or slang words. Also, the domicile of the respondents. All the respondents are living in Solo.
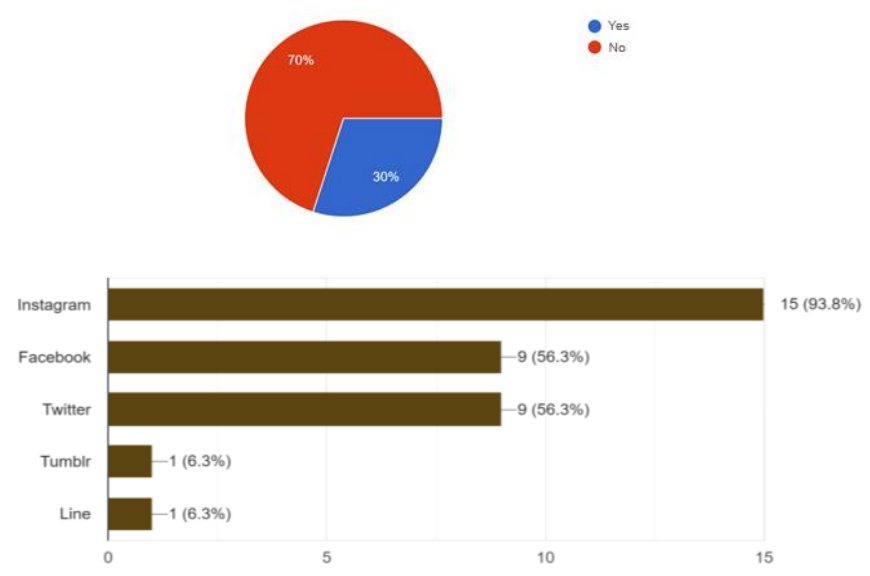

This one is about respondent's perspective about the product of KeKa Catering. To get and know the USP of KeKa Catering, I need some data from the repeat customer of KeKa Catering. That is why I asked them about their opinion according to the taste, price and service of KeKa Catering.

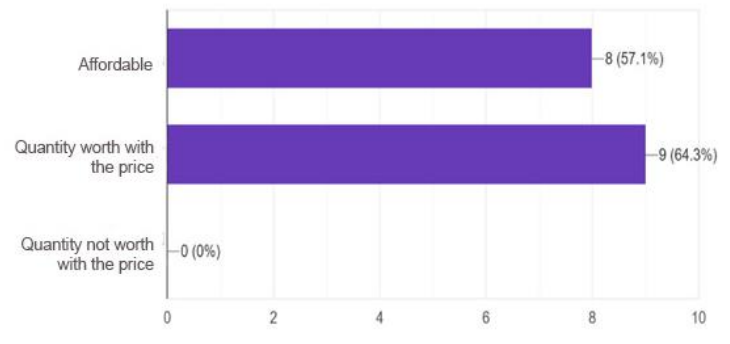

After spread the questionnaire and did some indirect interview with the customer, I got some USP and got some ideas for the Instagram content of KeKa Catering. The results show that the quality and quantity were the main USPs. Therefore, I used them in the tagline for the content of Instagram. The tagline that I used is "Rasa Nikmat, Perut Kenyang". "Rasa Nikmat" represent the quality of the product and "Perut Kenyang" represents the quantity. The content that they are going to have is about the products that they sell and also a little fact of the products. Facts in the contents will help the 
Callista: Increasing Brand Awareness of Keka Catering Through Social Media "Instagram"

customers to understand more about the product. The contents here are not formal, but more informal ones. This means it is going to look like a mini quiz for the customer. Because they will get curious about the fact that it is going to be uploaded. Also, I will discuss the choice of language that I used for the Instagram content, the logo that appeared in every picture and the last is about the hashtag in every caption of the content. There are nine hashtags, namely kekacatering, kuliner solo, catering solo, catering, kuliner, masakan, masakan banjarmasin, masakan banjar, fakta banjar.

There are four section for the contents. First section is the opening section of the fact of Banjarmasin's food. It contains two pictures and one pop up video. Next section, is the fact of Banjarmasin's food. There are three types of food, which are Soto Banjar, Sate Banjar and Nasi Kuning Banjar. The third section is the opening section of the fact of Banjarmasin's snacks. It is also contain two picture and one pop up video. Last section, is about the fact of Banjarmasin's snack. There are three types of snacks, which are Pastel Tutup Banjar, Pastel Goreng Banjar and Kompyang Banjar. I just explain about three types of foods and snacks because those are the one which being sold by KeKa Catering.

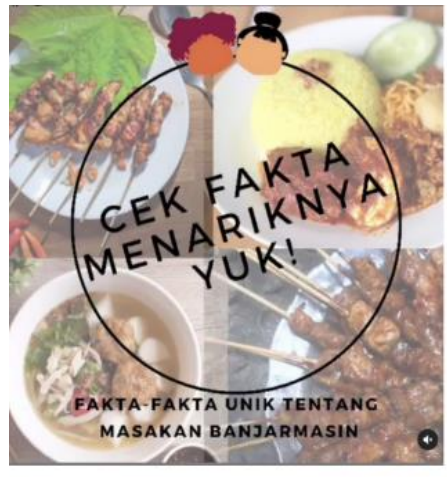

IFAKTAMENAR

RASA NIKMAT, PERUTPUN KENYANG

Mungkin makanan Banjarmasin ini tidak se-populer dan hits kaya makanan dan masakan Padang yang hampir di setiap kota ada rumah makannya

Eittsssss... tapi tunggu dulul! masakan Banjarmasin ini jug ngga kalah menarik dan nikmatnya lho karena memiliki cita rasa sendiri dan yang berbeda dari biasanya : : :

I use the Indonesian language because the target market is people who live in Solo. Furthermore, I use Indonesian slang words or internet words because the consumers of KeKa Catering are people who are around 19-25 years old. According to Stidham (2014), younger users of the internet tend to use slang words to make it faster and use several emoticons to describe the feeling.

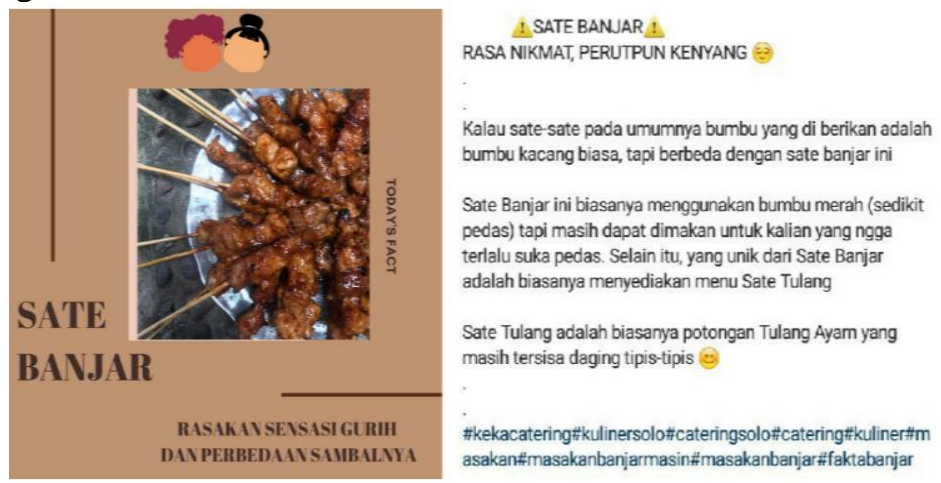

I use the logo of KeKa Catering in every picture of the content because according to the theory before that logo should be placed in the same place (Bansal, 2018). Should be placed in the same place because the customer could recognize the brand easily (Vallance, 2020). 

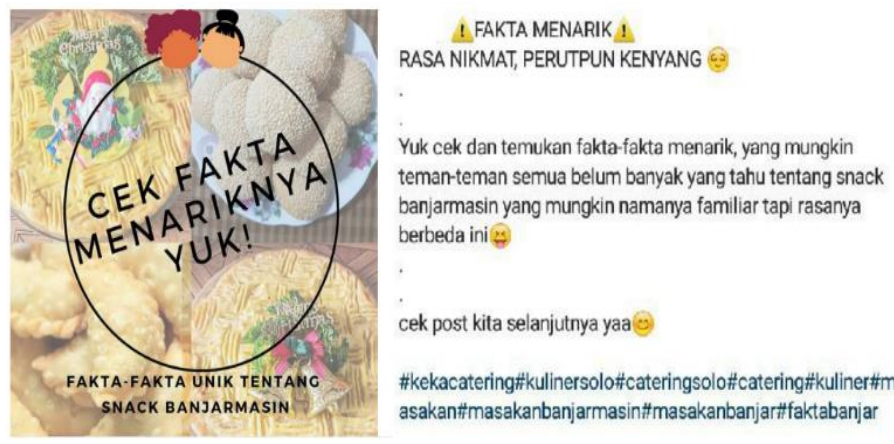

\#kekacatering\#kulinersolo\#cateringsolo\#catering\#kuliner\#m asakan\#masakanbanjarmasin\#masakanbanjar\#ffaktabanjar

The tagline is based on the USP because the result of USP almost all the customers feel satisfied with the taste of the product of KeKa Catering and the quantity worth the price. The tagline that I used for KeKa Catering is "Rasa Nikmat, Perutpun Kenyang ".

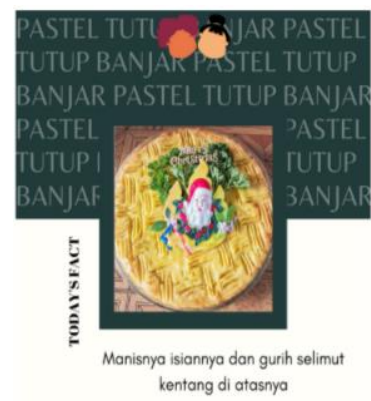

I PASTEL TUTUP: RASA NIKMAT, PERUTPUN KENYANG 9

Pastel tutup banjarmasin ini berbeda dengan yang lainnya karena lapisan kentang yang gurih dan isian yang ada cenderung memiliki rasa manis di bandingkan gurih

Selain itu, pastel tutup umumnya isiannya kering sedangkan pastel tutup banjarmasin ini basah (berkuah sedikit)

\#kekacatering\#kulinersolo\#cateringsolo\#catering\#kuliner\#m asakan\#masakanbanjarmasin\#masakanbanjartffaktabanjar

Next, about the hashtag, as we can see that every hashtag in the content is the same because the hashtag could make the brand of KeKa Catering visible to the outer customer, also it is the same in every continent to make it consistent (Bansal, 2018).

\section{CONCLUSION}

I choose to develop the Instagram business account of KeKa Catering for this creative thesis. I choose Instagram instead of a marketing booklet, flyer, and or brochure because KeKa Catering already has an Instagram account, but it is not run well. Second, the marketing booklet and other tools will cost more than Instagram. Furthermore, the customer of KeKa Catering all of them use Instagram even the ones who never buy KeKa Catering's product also use Instagram as their social media platform. Also, it will not spend so much energy to spread information about the product of it. However, to get this project of developing KeKa Catering's Instagram business account I need to discuss with the owner of KeKa Catering. I also did an online survey through a google form. I could not do it face to face with the customers because of the pandemic of COVID-19. I spread three different questionnaires which are the general questionnaire for the general customers, repeat order customers, and the one who never buy or do not know a product of KeKa Catering.

Instagram as online marketing here is to promote the product of KeKa Catering. It is because the content that going to be uploaded will have explanations and descriptions about the products in detail. The description just not in general, but for each product have each explanation and picture to 
Callista: Increasing Brand Awareness of Keka Catering

Through Social Media "Instagram"

give the image for the customers. Furthermore, the target market is broader because everyone could jump into KeKa Catering's Instagram account.

\section{REFERENCES}

Bansal, R. (2018). Brand Marketing on Instagram. Retrieved from https://play.google.com/books/reader?id=0868DwAAQBAJ\&pg=GBS.PP1

Clement, J. (2020). Instagram - Statistics \& Facts. Retrieved from https://www.statista.com/topics/1882/Instagram/

Howard, D., Mangold, W. G. and Johnston, T. (2014). Managing Your Social Media Campaign Strategy Using Facebook, Twitter, Instagram, Youtube and Pinterest: An Interview with Dana Howard, Social Media Marketing Manager. Retrieved from https://www.researchgate.net/publication/263391376_Managing_your_social_campaign_strat egy_using_Facebook_Twitter_Instagram_YouTube_Pinterest_An_interview_with_Dana_Ho ward_social_media_marketing_manager/link/5f1b2718a6fdcc9626b0046b/download

Massage, N. J. and Spa. (2020). Booming Sales With Instagram. Retrieved from https://books.google.co.id/books?id=UEjhDwAAQBAJ\&pg=PP8\&dq=how+to+maintain+an $\mathrm{d}+$ gain+Instagram+followers\&hl=en\&sa=X\&ved=2ahUKEwjwnoT6y6HsAhVa93MBHS39 CGEQ6AEwBXoECAQQAg\#v=onepage \&q\&f=false

Sasmita, J and Suki, N. M. (2014). Young Consumers' Insights on Brand Equity Effects of Brand Association, Brand Loyalty, Brand Awareness, and Brand Image. Retrieved from http://scholar.google.co.id/scholar_url?url=http://www.academia.edu/download/44542622/IJ RDM-02-20140024.pdf\&hl=en\&sa=X\&ei=ExfFX76WAojWyQSml5jgCQ\&scisig=AAGBfm0t3NxWl2s7f AS10Q13Z4eWLHUGdw\&nossl=1\&oi=scholarr

Social media. (2020). Merriam-webster.com. Retrieved from https://www.merriamwebster.com/dictionary/social\%20media

Vallance, S. (2020). The Evolution of Logos in Marketing: Where Did It All Begin?. Retrieved from https://visme.co/blog/evolution-oflogos/\#: :text=A\%20logo\%20is\%20the\%20graphic,the\%20public\%20in\%20an\%20instant 